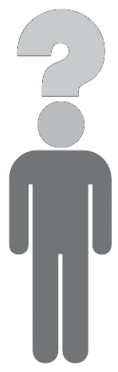

Anna Potoczek

\title{
ZJAWISKO MANIPULACJI DZIECKIEM W POLSKIEJ REKLAMIE UWARUNKOWANIA, ZAGROŻENIA, PREWENCJA
}

Wiecie, co jest reklama?... Jest to pył, co wlata Spod pióra dziennikarza pod powieki świata, Piasek ciskany w oczy w coraz większej dozie, Co jak w lecie kurzawa albo łzy na mrozie, Tak w nich sparaliżuje ścięgna, jasność, ruchy, Że nie zdołają słonia rozróżnić od muchy, Że na głos reklamistów, często arcyszczerze, Biorą niezdarny kołek za gotycką wieżę. (Jan Chęciński, Krytycy, akt III, s. 12)

Reklama i jej wpływ na człowieka od dekad jest ważnym tematem prac naukowców. W ciągu ostatnich kilkunastu lat intensywnie rozwinęły się jednak badania nad szczególnym jej rodzajem: reklamą dziecięcą. Zachodzące u progu XXI wieku zmiany sprawiły, że obiektem intensywnych działań marketingowo-komercyjnych stały się właśnie dzieci. Poniższa praca stanowi refleksję nad zmianami społecznymi, które doprowadziły do uzyskania przez dzieci statusu pełnoprawnych konsumentów, a także nad specyfiką prowadzonych współcześnie kampanii komercyjnych skierowanych do najmłodszych odbiorców.

Uznanie dziecka za ważną postać na rynku dóbr komercyjnych, nazywane przez Mateusza Halawę „komercjalizacją dzieciństwa”, ma głębokie podłoże społeczne ${ }^{1}$. Za jeden z głównych powodów tej zmiany można uznać fakt, iż młodzież, a nawet kilkulatki, zyskały znaczącą siłę nabywczą dzięki dysponowaniu własnymi zasobami i wywierają coraz większy wpływ na spo-

1 M. Halawa, Komercjalizacja dzieciństwa. Kosztorysowanie rodzicielstwa, [w:] Dziecko w świecie mediów i konsumpcji, red. M. Bogunia-Borowska, Kraków 2006, s. 45. 
żytkowanie budżetu domowego ${ }^{2}$. Oznacza to, że oprócz rynku pierwotnego, a więc własnego kapitału, jakim dysponują, dzieci tworzą także rynek wpływu, w ramach którego rodzice bądź to dokonują zakupów na prośbę dziecka, bądź tez za jego radą ${ }^{3}$. Fakt, że współczesne pokolenie dzieci i nastolatków jest pierwszym, które od urodzenia miało zapewniony dostęp do Internetu i nowoczesnych sprzętów elektronicznych, sprawia, że nierzadko jego przedstawiciele stają się „rzecznikami” marki i traktowani są jako specjaliści i doradcy w kwestii zakupu produktów będących technologicznymi „nowinkami". Z tego też powodu reklamodawcy kierują do nich przekazy dotyczące produktów przeznaczonych nie tylko dla ich własnego użytku, ale także dla użytku ich rodziców ${ }^{4}$.

Ponadto socjologowie zwracają uwagę na problem, jaki stanowi obecnie nieumiejętność oceny przez dzieci wartości pieniądza. Jak zauważa Małgorzata Bogunia-Borowska, dziecko staje się coraz bardziej wycofane z życia zawodowego rodziców, a coraz wcześniej wkracza w życie konsumpcyjnego społeczeństwa ${ }^{5}$. Jeszcze niewiele dekad temu dzieci mogły obserwować, a nierzadko uczestniczyć w pracy rodziców, co jednocześnie wiązało się ze świadomością, za co ich rodzice otrzymują wynagrodzenie. Obecnie sfera zawodowa rodziców jest oddzielona od życia dziecka, tak że coraz częściej zdobywanie pieniędzy kojarzy mu się z ich pozyskiwaniem z maszyn na ulicach i w bankach w prosty i szybki sposób 6 .

Wreszcie zjawisku „komercjalizacji dzieciństwa” sprzyja wzrost poziomu życia i zmniejszanie się liczby posiadanego potomstwa we współczesnych rodzinach - rodzice, wychowując coraz mniejszą liczbę dzieci, mogą przeznaczać na nie coraz większe zasoby.

W Polsce na korzyść reklamodawców działa również liberalne prawo reklamowe; nie istnieje tu żaden spójny akt prawny regulujący emisję działalności reklamowej. Dokumenty prawne takie jak Ustawa z dnia 16 kwietnia 1993 r. o zwalczaniu nieuczciwej konkurencji czy Ustawa z dnia 29 grudnia 1992 r. o radiofonii i telewizji wprowadzają zakazy dość oczywiste, jak na przykład niemoż-

\footnotetext{
M. Lindstrom, Dziecko reklamy, Warszawa 2005, s. 34.

M. Halawa, Komercjalizacja dzieciństwa, dz. cyt., s. 49.

M. Lindstrom, Dziecko reklamy, dz. cyt., s. 85.

M. Bogunia-Borowska, Dziecko w świecie mediów i konsumpcji, Kraków 2006, s. 9.

Tamże, s. 9.
} 
ność reklamowania wyrobów alkoholowych i tytoniowych w prasie i telewizji dziecięcej. Z kolei wewnętrzne reguły telewizji publicznej zakładają odmowę emisji reklam agencji towarzyskich czy produktów erotycznych. Również obostrzenia zakazujące reklam zagrażających fizycznemu rozwojowi dziecka wydają się zupełnie nieprzystające do rzeczywistości, w której głównym problemem mediów staje się manipulacja poglądami dziecka7.

Najskuteczniejszym środkiem przekazu od lat pozostaje reklama telewizyjna. Ma ona tak ogromną siłę oddziaływania na dziecko, ponieważ wyprzedza wpływ nie tylko przedszkola i szkoły, ale częstokroć nawet grupy rówieśniczej8.

Według badań Tatiany Kłosińskiej przeprowadzonych na grupie 10-latków średni czas oglądania telewizji przez dzieci waha się od średnio trzech godzin $w$ dni powszednie aż do pięciu godzin w weekendy9. Najskuteczniejsze okazuje się kierowanie reklam do dzieci w wieku przedszkolnym i wczesnoszkolnym, kiedy nie posiadają one kompetencji do obiektywnej analizy treści reklamowych - dzieci nie wykazują krytycyzmu wobec reklam i nie zauważają zawartej w nich perswazji ${ }^{10}$.

O takim postrzeganiu świata przez dzieci świadczą badania przeprowadzone przez Marię Braun-Gałkowską na próbie przedszkolaków. Autorka przytacza niektóre z komentarzy kilkulatków po obejrzeniu przez nich reklam chipsów i batonów, świadczące o ich nieumiejętności krytycznej analizy odbieranych treści i dużej podatności na manipulację:

Zosia, lat 5,5: Baton mówi: Zjedz mnie albo weź szybko do domu, bo boję się, że się rozpuszczę. [...] Jak mnie zjesz, będziesz taka sama miła, jak ja, będziesz zdrowa. Jak mnie zjesz, będziesz pomagała koleżankom, będziesz umiała podlewać kwiatki, ładnie rysować i kolorować. [...] Będę umiała różne prace, liczyć, pisać litery, urosną mi włosy, będę umiała podnosić ciężary.

Kasia, lat 5,5: Chciałabym zjeść takiego batona, bo bym była silna i miałabym pieniądze i kupiłabym różne rzeczy [...]. Dzieci dostają siły i szybko rosną i nie chorują wcale.

7 T. Kłosińska, Dziecko wobec mediów: wyzwania wychowawcze, [w:] Rodzina: historia i współczesność, red. W. Korzeniowska, U. Szuścik, Kraków 2006, s. 299.

8 W. Tuszyńska-Bogucka, Dziecko w świecie telewizji, [w:] Media - przyjaciel czy wróg dziecka? Program informacyjno-edukacyjny, red. W. Tuszyńska-Bogucka, Poznań 2006, s. 37.

9 T. Kłosińska, Oddziaływanie programów i reklam telewizyjnych na dzieci, [w:] Kompetencje medialne społeczeństwa wiedzy, red. W. Strykowski, W. Skrzydlewski, Poznań 2004, s. 405.

10 Tamże, s. 407. 
Paweł, lat 5: Chciałbym jeść te chrupki, bo ich nigdy nie jadłem, a jak się zje, to się jest takim silnym. Miałbym siłę, mógłbym wszystkich obronić, wszyscy by podziwiali moje muskuły, chcieliby się ze mną bawić ${ }^{11}$.

Kilkuletnie dzieci są bardzo entuzjastyczne nawet wobec reklam emitowanych w czasie przerw między bajkami, często traktując je jako film czy kreskówkę. Dlatego specjaliści od reklamy jak najbardziej próbują upodobnić ją do bajek: przekaz jest animowany, a treść przekazywana w formie piosenki ${ }^{12}$. Producenci doskonale zdają sobie sprawę również z innej „przypadłości” wieku dziecięcego, jaką jest podatność na wpływy wzorców i ogromna chęć ich naśladowania. Dlatego nieprzypadkowo w reklamach dla dzieci narratorami są ich ukochani bohaterowie bajek, którzy namawiają do kupna określonych produktów $^{13}$.

Reklamy dla dzieci charakteryzują się także specyficznym językiem: powszechne są powtórzenia, zdrobnienia, rymowanki, aliteracje, słownictwo magiczne i używanie wyrazów aktualnie modnych ${ }^{14}$. Szczególny jest także język reklam produktów dziecięcych, których treść skierowana jest do rodziców. Jadwiga Lizak w swojej pracy na temat języka reklam dla dzieci stwierdza, że współcześnie typowy przekaz reklamowy daje wpisać w poniższy schemat: „każda matka, która kocha swoje dziecko, powinna kupować produkt X, ponieważ jest on bezpieczny, gdyż został przebadany i cieszy się dobrą opinią specjalistów, stworzono go z myślą o Twoim dziecku i Twojemu dziecku przyniesie on radość i szczęście"15.

Oznacza to, że coraz popularniejszym zjawiskiem, opisywanym przez Halawę, jest „kosztorysowanie rodzicielstwa”, a więc definiowanie go poprzez kategorie rynkowe ${ }^{16}$. Media ukazują macierzyństwo i ojcostwo głównie jako zaspokajanie potrzeb finansowych dzieci, często przez same media wykreowanych. Reklamy ustawicznie kwestionują autorytet rodziców poprzez przedstawianie wizerunku dobrej matki i ojca jako troszczących się o swoje pociechy poprzez kupowanie im reklamowanych produktów. Jak pisze Halawa, coraz częściej do-

11 M. Braun-Gałkowska, Dzieci - odbiorcy reklam, „Wychowawca” 7-8 (2002), s. 11.

12 J. Lizak, Język reklam dla dzieci, Rzeszów 2006, s. 144.

13 M. Braun-Gałkowska, Dzieci - odbiorcy reklam, dz. cyt., s. 12.

14 J. Lizak, Język reklam dla dzieci, dz. cyt., s. 143.

15 Tamże, s. 89.

16 M. Halawa, Komercjalizacja dzieciństwa, dz. cyt., s. 45. 
rośli ludzie - odbiorcy reklam - mogą odnieść wrażenie, że „nie można być pełnoprawnym rodzicem, nie będąc pełnoprawnym konsumentem" ${ }^{17}$.

Producenci reklam nie powstrzymują się także przed wykorzystywaniem dzieci jako narzędzia do manipulacji osobami dorosłymi. Doliński opisuje ten mechanizm, posługując się fenomenem odkrytym przez Konrada Lorenza zwanym „schematem dziecięcości” ${ }^{18}$. Zjawisko to polega na wyzwalaniu w jednostce instynktownych, życzliwych zachowań, których celem jest ochrona bezbronnych, niedorosłych przedstawicieli gatunku. Nie bez przyczyny więc na wielu produktach, takich jak odżywki czy kaszki, znajdują się niemowlęta wywołujące automatyczne uczucie rozczulenia - silne emocje pozytywne skojarzone zostają z promowanym w reklamie produktem, co sprzyja kupnu opisywanych dóbr ${ }^{19}$. W związku z tym specjaliści podnieśli temat konieczności ochrony nie tylko dzieci, ale także dorosłych, uznając podobne wykorzystywanie ludzkich słabości za nieetyczne.

Uproszczona, sielankowa wizja świata lansowana w reklamach wykształca w dzieciach nierealne oczekiwania co do standardów życia i kreuje u nich pragnienia, których wcześniej sobie nie uświadamiały, a ich zestawienie z rzeczywistością wywołuje frustrację i niechęć do otoczenia ${ }^{20}$. Istotnie, według badań przeprowadzonych przez Kłosińską aż 80 proc. rodziców trzecioklasistów przyznaje, że odmowa zakupu reklamowanych produktów doprowadza do konfliktu $w$ rodzinie ${ }^{21}$.

O ile jednak problem manipulacji dzieckiem w reklamie telewizyjnej i jej szkodliwości od dawna jest nagłaśniany, o tyle czytelnictwo przedstawiane jest jako przeciwwaga i alternatywne rozwiązanie, które swoim dzieciom proponować powinni uświadomieni rodzice. Tym samym przekazy reklamowe zawarte w czasopismach dla dzieci stają się szczególnie zdradliwą formą manipulacji; rodzice z najlepszymi intencjami kupują swoim pociechom gazety, często nie zdając sobie sprawy z tego, jaką dawkę ogłoszeń reklamowych im zapewniają. Współcześnie dorosły człowiek może mieć poważne problemy z odróżnieniem niereklamowych części czasopisma od reklamy, dla dziecka zaś przekaz eduka-

17 Tamże, s. 55.

18 D. Doliński, Psychologia reklamy, Wrocław 2001, s. 136.

19 Tamże, s. 139.

20 T. Kłosińska, Dziecko wobec mediów..., dz. cyt., s. 300.

21 Tamże, s. 408. 
cyjny stapia się w całość z ofertami komercyjnymi specjalnie wystylizowanymi na nieróżniące się od pozostałych części czasopism. Co więcej, dziecko traktuje je jako wiarygodne źródło informacji, dlatego tym trudniej przychodzi mu oparcie się manipulacjii22.

Jak się okazuje, z reklamami spotkać się możemy nie tylko w pismach dla dzieci, które już nauczyły się czytać; indoktrynacja zaczyna się znacznie wcześniej. Logo danego produktu niepostrzeżenie umieszczane jest na okładkach różnego rodzaju wydawnictw przeznaczonych dla dzieci: kolorowanek, wyklejanek itp. (jak na przykład logo firmy Tymbark umieszczone na kolorowance dla dzieci w wieku od 3 lat wydawanej przez wydawnictwo AMET)23. Mimo że dzieci nie potrafią przeczytać jeszcze napisu, są zaznajamiane z logo firmy, co ma na celu wyrobienie u nich świadomości marki. Oprócz dwóch wspomnianych wcześniej rynków, pierwotnego i wpływu, reklamodawcy dostrzegają tu trzeci rynek, na którym dziecko jest przyszłym potencjalnym klientem, zaś jak wskazują eksperci w dziedzinie marketingu, sama obecność marki w życiu odbiorcy jest pierwszym krokiem do zbudowania u niego lojalności wobec firmy ${ }^{24}$.

Pełna kampania reklamowa zaczyna się jednak dopiero w książeczkach i gazetach dla dzieci potrafiących czytać. Czasopismem, na którego przykładzie zaprezentowane zostaną sposoby manipulacji dzieckiem w wieku wczesnoszkolnym, jest miesięcznik „TOPModel”. Sam wydawca, Egmont Polska Sp. z. o.o., opisuje go poniższymi słowami:

Pismo adresowane jest do dziewczynek w wieku od 6 do 12 lat, które interesują się modą i lubią projektować stroje. Główne bohaterki pisma - tytułowe Top Models - przybliżają nowinki ze świata mody, pokazują, co jest trendy, a co passé, jakie ubrania z czym zestawić. Na poszczególnych stronach znajdują się również liczne porady dotyczące makijażu, fryzur, samego ubioru, dodatków i akcesoriów ${ }^{25}$.

Rozkład czasopisma do złudzenia przypomina prasę kobiecą. Na pierwszej stronie główna bohaterka - modelka Louise - informuje, co jest „na topie”, a co jest już niemodne, jednocześnie uspokajając zaniepokojone czytelniczki:

Tamże, s. 407.

DISNEY Kubuś i przyjaciele, Kolorowanka, Wyd. AMEET, 18 stron. Grupa docelowa: dzieci od 3. roku życia.

M. Lindstrom, Dziecko reklamy, dz. cyt., s. 75.

Ł. Szewczyk, TOPModel - nowe czasopismo dla młodych kreatorek mody, http://media2.pl/media/90399-TOPModel-nowe-czasopismo-dla-mlodych-kreatorek-mody.html (8.09.2013). 
Jesteś przerażona, bo nadchodzi jesień, a w twojej szafie nie ma nic fajnego, co by się nadawało na chłodniejsze dni? Brak botków i modnych swetrów spędza ci sen z powiek? Wyluzuj! Jeszcze nie pora martwić się jesienną garderobą. Póki co ciesz się z noszenia zwiewnych sukienek i krótkich szortów. Jesień i tak nas dopadnie ${ }^{26}$.

Mimo tego zapewnienia narratorka czasopisma zachęca jednak do zakupienia „modnych już kolejny sezon botków” marki Reserved. Okazuje się, że nie znajdujemy tu już reklam zabawek lub jest ich bardzo mało - w tym czasopiśmie przeznaczonym dla dziewczynek uczących się w szkole podstawowej na pierwszy plan przebijają się ubrania i kosmetyki.

Większość stron „TOPModel” poświęconych jest właśnie modzie, przy czym każda z nich jest opatrzona radą ekspertki - jednej z bohaterek czasopisma. Element ten jest odzwierciedleniem rad eksperta - dentysty - w reklamach past do zębów czy hydraulika w reklamach proszków do prania, dostarczających społeczny dowód słuszności ${ }^{27}$. Wszystkie ubrania opatrzone są oczywiście odsyłaczem do nazwy sklepu, w którym można je zakupić, oraz ceną.

Im starsze dzieci i im bardziej odporne na manipulację, tym produkt musi być lepiej ukryty, a wskazanie konkretnych producentów lepiej uzasadnione. $\mathrm{Na}$ przykładzie czasopisma dla młodzieży gimnazjalnej „Bravo” autorka postara się przedstawić technikę product placement, której celem jest docieranie do podświadomości odbiorcy i zachęcanie do kupna produktów bez oczywistej, jawnej reklamy ${ }^{28}$.

Na pierwszej stronie czasopisma znajduje się dział In and out, analogiczny do tego w poprzednim czasopiśmie, w którym czytelnik dowiedzieć się może, co należy kupować w tym miesiącu, a co odeszło do lamusa. Jednym z pożądanych produktów jest na przykład nowa owocowa guma do żucia marki Orbit. Podobne metody odnaleźć możemy w dziale porad zdrowotnych, w których czasopismo przedstawia rzekome prośby o pomoc czytelniczek i odpowiedzi specjalistów. Na przykład na pytanie, czy przy noszeniu aparatu trzeba dbać o jamę ustną, „Bravo” odpowiada: tak, używając płynu Listerine i pasty Colgate.

26 „TOPModel”. Miesięcznik, Wyd. Egmont Polska, licencja: Depeche Vertrieb GmbH \& Co. 52 strony. Grupa docelowa: dziewczynki 6-12 lat. Cena: 7,99 zł. Wszystkie cytaty przytaczane w powyższej pracy pochodzą z nr. 3 (2012).

27 B. Wojciszke, Psychologia społeczna, Warszawa 2011, s. 284.

28 D. Doliński, Psychologiczne mechanizmy reklamy, Gdańsk 2008, s. 43. 
Na pytanie, co pomoże na trądzik, czasopismo udziela odpowiedzi, że należy zakupić suplement diety Cera Nova, którego reklama zamieszczona jest w numerze jeszcze kilkukrotnie. Biorąc pod uwagę, że nigdzie nie zostało napisane, że to reklama, porady te zaliczają się do niereklamowych treści czasopisma ${ }^{29}$.

Główną rolą kolorowych pisemek dla dzieci okazuje się kształtowanie przyszłych konsumentów: posiadanie dóbr materialnych zostaje uznane za nadrzędny cel życia, dzięki któremu uzyskać można odrębność, wysoką pozycję społeczną i podziw rówieśników. Robienie zakupów uznane zostaje za główny i najprzyjemniejszy zarazem sposób spędzania wolnego czasu. Dziecko, zapoznając się z treścią reklam, niechybnie dochodzi do wniosku, że tylko poprzez markowe produkty jest w stanie „wynegocjować” odpowiednią pozycję wśród rówieśników i zająć wysokie miejsce w dziecięcych hierarchiach ${ }^{30}$. Jak wskazują specjaliści od marketingu, współcześnie symbole konkretnych marek stają się wręcz symbolem tożsamości, pozwalającym najmłodszym konsumentom na samookreślenie, a nawet zapewniającym poczucie bezpieczeństwa w otaczającym środowisku².

Stosowanie podobnych mechanizmów wobec dzieci już od najmłodszych lat może okazać się brzemienne w skutkach w całym ich dorosłym życiu. Wszechobecne promowanie kultu pieniądza i dóbr materialnych i ukazywanie ich jako główny sens życia człowieka doprowadzić może w dorosłości do realizowania wartości opartych głównie, o ile nie wyłącznie, na konsumpcjonizmie. W świecie reklamy cechy człowieka i jego działania schodzą na drugi plan - wyznacznikiem wartości stają się zakupione przedmioty, zaś posiadanie i dążenie do posiadania coraz większej ilości dóbr wyraźnie wpływa na postrzeganie przez ów pryzmat siebie i innych.

Jak można zauważyć, im starsze dziecko, tym odbiorcy bardziej starają się zakamuflować manipulację - od jawnego zamieszczania logo produktu na okładce gazety po umieszczaniu reklam w kąciku porad. Jednym z najczęściej, obok product placement, wykorzystywanych w czasopismach dla dzieci form reklamy jest także „reklamo-rozrywka” (ang. advertainment), która wymaga od dziecka nie tylko przeczytania informacji o produkcie, ale także poświęcenia jej

29 „Bravo”. Dwutygodnik. Wyd. Bauer. 64 strony. Grupa docelowa: młodzież w wieku 15-19 lat. Cena: 2,60 zł. Wszystkie cytaty przytaczane w powyższej pracy pochodzą z nr. 20 (2012).

30 M. Halawa, Komercjalizacja dzieciństwa, dz. cyt., s. 50.

31 M. Lindstrom, Dziecko reklamy, dz. cyt., s. 34. 
czasu. Dzięki temu w oczach dziecka reklamodawca nie traci na wiarygodności i powstrzymuje je od sceptycyzmu, który mogłyby wywołać w odbiorcach bezpośrednie reklamy ${ }^{32}$.

I tak na przykład „Bravo” zachęca swoich czytelników do wzięcia udziału w konkursie dla wybrańców - tych, których numer telefonu zaczyna się i kończy na cyfry sąsiadujące ze sobą w tabelce. Jak można zauważyć po jej krótkim przestudiowaniu, każda cyfra od 6 do 9, czyli możliwe początkowe cyfry numerów komórkowych sąsiaduje z każdą inną cyfrą, na którą może kończyć się numer. „Bravo” stwarza jednak atmosferę elitarności pisząc: „Na szczęśliwców czekają nagrody! Jeśli twój numer okazał się szczęśliwy, czym prędzej wyślij SMS!". Zabieg ten wywołuje w dzieciach i młodzieży wrażenie, że od wygranej dzieli ich już tylko krok i chętniej niż w zwykłym konkursie wysyłają SMS-y, padając tym samym ofiarą manipulacji ze strony wydawcy.

Przedstawione powyżej przykłady reklam pochodzą ze środków masowego przekazu. Coraz częściej jednak dziecko na reklamową manipulację narażone zostaje także w placówkach edukacyjnych. Wynika to z faktu, iż współcześnie bardzo popularną formą reklamy stało się promowanie produktów poprzez reklamę w szkołach, co przybiera pozór nauki poprzez rozrywkę; w postaci materiałów edukacyjnych rozprowadzanych wśród dzieci reklamodawcy przekazują treści komercyjne. Taka forma reklamy sprawdza się najbardziej w placówkach borykających się z problemami finansowymi, a więc w przypadku Polski - w większości szkół publicznych. Za cenę „mniejszego zła” polegającego na wystawianiu dzieci na oddziaływanie manipulacji producentów nauczyciele podejmują współpracę z reklamodawcami w celu zapewnienia uczniom sprzętu i materiałów, na które władze szkół w normalnych warunkach nie mogłyby sobie pozwolić33.

W 2012 roku rodzice z całej Polski oburzeni indoktrynacją swoich dzieci założyli na portalu społecznościowym Facebook stronę „Stop reklamom w przedszkolach", która sprzeciwia się manipulacji dziećmi podczas ich pobytu w przedszkolu i na której rodzice wspólnie tworzą bazę zdjęć i relacji z kampanii reklamowych przeprowadzanych z udziałem ich dzieci ${ }^{34}$. Jak się okazuje,

32 Tamże, s. 272.

33 Tamże, s. 265.

34 Stop reklamom w przedszkolach, https://www.facebook.com/StopReklamomWPrzedszkolach (8.09.2013). 
reklamodawcy coraz częściej nie ograniczają się jedynie do reklamy produktów przeznaczonych dla najmłodszych konsumentów. Przedszkolaki są przymusowo zabierane na otwieranie nowych filii firm takich jak Kredyt Chwilówka i Tesco, do placówek przybywają zaś przedstawiciele spółek zajmujących się sprzedażą opon samochodowych czy środków czystości. Kampanie reklamowe w formie zabawy połączone z degustacją produktów spożywczych stają się stałym elementem zajęć przedszkolnych, przy czym coraz częściej dzieci nie są tylko biernymi odbiorcami takiej formy reklamy, ale są także przez swoich wychowawców czynnie w nią angażowane.

Przykład tego rodzaju kampanii stanowić mogą Dni Marchewki organizowane w przedszkolach w całej Polsce przez producenta soku Kubuś, firmę Tymbark S.A. Rodzice kilkulatków uprzednio proszeni są o ubranie dziecka na pomarańczowo, zaś stałym elementem tego wydarzenia jest nakazanie dzieciom odtańczenia „marchewkowego tańca” wokół ustawionych na ziemi butelek soku. Większość tego rodzaju imprez organizowanych w placówkach edukacyjno-wychowawczych jest następnie dokumentowana na ich stronach internetowych. I tak na przykład na portalu należącym do gminy Malechowo przeczytać można entuzjastyczną relację:

W każdej grupie przedszkolnej czekały na dzieci wesołe, marchewkowe niespodzianki. Maluszki odtańczyły „marchewkowy taniec”, dowiedziały się, jak powstaje marchewkowy sok Kubuś, spróbowały swoich sił w tarciu marchewki i zajadały się marchewką. [...] Następnie, rzecz jasna, nastąpiła degustacja i surówki, i soku z marchwi. Ten dzień był inny od wszystkich - pomarańczowy, marchewkowy, zakręcony... Śmiechu było co niemiara - ale o to właśnie chodziło. Po takiej dawce witamin, śmiechu i zabawy na pewno wszystkie przedszkolaki będą zdrowe i uśmiechnięte ${ }^{35}$.

To tylko jedna z wielu akcji, w jakich przymusowo biorą udział dzieci uczęszczające do polskich przedszkoli.

Być może pokolenie rodziców obecnych przedszkolaków jest ostatnim, które będzie w stanie sprzeciwić się podobnej indoktrynacji. Dzieci wychowujące się we współczesnych przedszkolach są bowiem uczone, że reklama jest nieodłącznym elementem codziennego życia, a kampanie reklamowe nie mogą być czymś złym, skoro popierane są przez autorytety, takie jak wychowawcy przed-

35 D. Sieklucka, Dzień Marchewki w przedszkolu w Malechowie, http://www.malechowo.pl/ 499-4a1a5faf4361e-21035-p_144.htm (8.09.2013). 
szkolni czy władze placówki. Kolejny problem stanowi również wprowadzanie dzieci w błąd i wywoływanie u nich dezinformacji poprzez promowanie poglądu, iż za zdrowe możemy uznać wyłącznie lub głównie produkty posiadające konkretne marki.

Podsumowując, w ostatnich dziesięcioleciach nastąpiły zmiany społeczne, które doprowadziły do traktowania dziecka jak pełnoprawnego konsumenta, a przez to nasilenia skierowanych do dzieci kampanii reklamowych, nierzadko uciekających się do manipulacji. Takiej sytuacji sprzyja zaś liberalne prawo w Polsce, zezwalające na występowanie w reklamach dzieci i emitowania przekazów skierowanych nawet do kilkulatków. Jak udowadniano powyżej, obecnie producenci zabawek czy artykułów żywnościowych nie ograniczają kampanii reklamowych tylko do telewizji czy czasopism: wychodzą dziecku naprzeciw, odwiedzając je podczas zajęć w szkole i przedszkolu. Dlatego też we współczesnym świecie oferującym dzieciom mnogość produktów, czasopism i programów rodzice muszą być jeszcze ostrożniejsi i bardziej kontrolować media, z których korzystają ich dzieci. Warto wreszcie stwierdzić, że telewizja i czasopisma stanowią nie tylko zagrożenie, ale także stwarzają odbiorcom wiele możliwości, zapewniają przekaz ważnych i potrzebnych dziecku wiadomości. Jak pisze Teresa Król:

Byłoby niesprawiedliwością niedostrzeganie wartości, które daje telewizja dzieciom i młodzieży. Problem polega tylko na tym, że jest ich niewiele i że trzeba umieć je wskazać i wykorzystać, a rodzice i wychowawcy nie zawsze to czynią?

\section{Bibliografia}

Braun-Gałkowska M., Dzieci - odbiorcy reklam, „Wychowawca” 7-8 (2002), s. 10-14.

Bromboszcz E., Percepcja reklamy telewizyjnej przez dzieci, „Psychologia Wychowawcza" 1 (1993).

Doliński D., Psychologia reklamy, Wrocław 2001.

Doliński D., Psychologiczne mechanizmy reklamy, Gdańsk 2008.

Halawa M., Komercjalizacja dzieciństwa. Kosztorysowanie rodzicielstwa, [w:] Dziecko w świecie mediów i konsumpcji, red. M. Bogunia-Borowska, Kraków 2006, s. 45-55.

36 T. Król, Wpływ telewizji na zachowania agresywne dzieci i młodzieży, „Psychologia i Rzeczywistość", czasopismo internetowe, 1 (2003). 
Kłosińska T., Dziecko wobec mediów: wyzwania wychowawcze, [w:] Rodzina: historia i współczesność, red. W. Korzeniowska, U. Szuścik, Kraków 2006, s. 291-304.

Kłosińska T., Oddziaływanie programów i reklam telewizyjnych na dzieci, [w:] Kompetencje medialne społeczeństwa wiedzy, red. W. Strykowski, W. Skrzydlewski, Poznań 2004, s. 404-411.

Król T., Wpływ telewizji na zachowania agresywne dzieci i młodzieży, „Psychologia i Rzeczywistość", czasopismo internetowe, 1 (2003).

Lindstrom M., Dziecko reklamy, Warszawa 2005.

Marmoł A., Zabiegi manipulacyjne w reklamach telewizyjnych kierowanych do dzieci, [w:] Wczesna edukacja dziecka - perspektywy i zagrożenia, pod red. S. Włoch, Opole 2009, s. 263-268.

Sieklucka D., Dzień Marchewki w Przedszkolu w Malechowie, http://www.malechowo. pl/499-4a1a5faf4361e-21035-p_144.htm.

Szewczyk Ł., TOPModel - nowe czasopismo dla młodych kreatorek mody, http://media2.

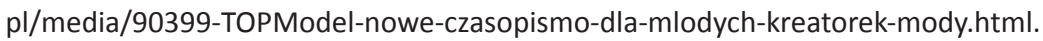

Tuszyńska-Bogucka W., Dziecko w świecie telewizji, [w:] Media - przyjaciel czy wróg dziecka? Program informacyjno-edukacyjny, red. W. Tuszyńska-Bogucka, Poznań 2006, s. 35-45.

Wojciszke B., Psychologia społeczna, Warszawa 2011. 